\title{
Aplikasi Umbi Suweg (Amorphophallus campanulatus) sebagai Alternatif Penurun Gula Darah pada Penderita Diabetes Mellitus
}

\author{
Lianah", Dian Ayuning Tyas' ${ }^{2}$, Dian Triastari Armanda ${ }^{3}$, Siti Mukhlishoh Setyawati ${ }^{4}$ \\ Prodi Pendidikan Biologi, Fakultas Sains dan Teknologi, UIN Walisongo Semarang \\ Email: ${ }^{1}$ lianah@walisongo.ac.id, ${ }^{2}$ da.tyas@walisongo.ac.id, ${ }^{3}$ dian.armanda@walisongo.ac.id, \\ ${ }^{4}$ siti.mukhlishoh@walisongo.ac.id
}

\begin{abstract}
Abstrak
Penelitian ini bertujuan untuk mempelajari perbandingan kadar glukosa darah tikus putih (Rattus norvegicus L.) setelah mengonsumsi suweg mentah dan suweg rebus. Eksperimen dilakukan pada 15 ekor tikus putih sehat dengan rerata berat badan 181-183 gram. Tikus dibagi menjadi 3 kelompok perlakuan. Setiap kelompok tikus normal diadaptasikan terhadap pakan selama 3 hari dan dipuasakan selama 8-12 jam, kemudian diberi pakan sesuai dengan kelompok perlakuan masing-masing pakan suweg dengan dosis $10 \mathrm{mg} / 180 \mathrm{~g}$ BB suweg rebus, $10 \mathrm{mg} / 180 \mathrm{~g}$ BB suweg mentah, dan $10 \mathrm{mg} / 180 \mathrm{~g}$ BB pakan standar (kontrol). Kadar glukosa darah diukur dengan glukometer pada menit ke 0, 60 dan 120 setelah pemberian pakan secara oral. Hasil menunjukkan bahwa perlakuan umbi suweg mentah menunjukkan aktivitas penurunan kadar gula darah lebih tinggi $(3,8 \mathrm{mg} / \mathrm{dl})$ dibandingkan umbi suweg rebus $(3,6$ $\mathrm{mg} / \mathrm{dl}$ ). Kecenderungan ini menunjukkan bahwa secara alami hormon insulin di dalam tubuh tikus sudah bekerja dalam menyeimbangkan kadar gula darah. Suweg mengandung senyawa bioaktif berupa Polisakarida Larut Air (PLA) dan serat pangan yang dapat membantu menurunkan kadar glukosa darah. Umbi suweg dapat diaplikasikan pada manusia khususnya sebagai terapi diet penurun kadar glukosa darah bagi penderita diabetes mellitus.

Kata kunci: Umbi suweg, penurun glokosa darah, diabetes mellitus
\end{abstract}

\section{Pendahuluan}

Suweg (Amorphophallus campanulatus) merupakan tanaman umbi-umbian yang memiliki kadar karbohidrat paling kecil 15,8 g per $100 \mathrm{~g}$ bahan. Tanaman tersebut belum dimanfaatkan secara optimal oleh masyarakat Indonesia. Umbiprotein dan asam amino, sterol dan terpenoid, karbohidrat, lemak dan minyak. Suweg belum banyak dimanfaatkan secara optimal. Sebagai sumber bahan pangan, suweg sangat potensial, karena dilihat dari komposisinya setiap $100 \mathrm{~g}$ suweg mengandung protein $1.0 \mathrm{~g}$, lemak $0.1 \mathrm{~g}$, karbohidrat $15.7 \mathrm{~g}$, kalsium $62 \mathrm{mg}$, besi $4.2 \mathrm{~g}$, thiamine $0.07 \mathrm{mg}$ dan asam askorbat $5 \mathrm{mg}$. Suweg merupakan jenis umbi-umbian yang mempunyai kadar pati sebesar 18,44\% (Utomo dan Antarlina, 1997). Pati suweg adalah tepung pati yang umbian tersebut selain sebagai makanan selingan makanan pokok karena kandungan karbohidratnya, juga diduga mempunyai khasiat obat. De et al. (2010) dalam penelitiannya menunjukkan bahwa suweg mengandung alkaloid, tanin, flavonoid

diperoleh dari proses ekstraksi umbi suweg. Kadar pati dalam pati sebesar 88,5\%. Keunggulan pati suweg antara lain mempunyai kadar amilopektin yang tinggi yaitu 75,5\% (Wankhede dan Sajjan, 1981). Dari kandungan amilopektin tersebut dapat dimanfaatkan untuk pembuatan dekstrin. Dekstrin merupakan polisakarida dengan berat molekul sekitar 50.000. Dekstrin terdiri dari rantai dengan ikatan $\alpha-1,6$ dan $\alpha-1,4$ (Winarno, 2002). Dekstrin biasanya diperoleh dari hidrolisis pati dengan enzim amilase. Pemutusan ikatan rantai pada 
hidrolisis parsial amilopektin menyebabkan dekstrin yang terbentuk hampir menyerupai gula (Ruqoiyah, 2002).

Diabetes mellitus atau yang lebih dikenal dengan penyakit gula atau kencing manis diakibatkan oleh kekurangan hormon insulin (Tjokroprawiro, 1988). Hal ini disebabkan oleh pankreas sebagai produsen insulin tidak memproduksi insulin dalam jumlah yang cukup besar daripada yang dibutuhkan oleh tubuh, sehingga pembakaran dan penggunaan karbohidrat tidak sempurna (Tjokroprawiro, 1986). Dalam penanggulangan diabetes, obat hanya merupakan pelengkap dari diet. Obat hanya perlu diberikan bila pengaturan diet secara maksimal tidak berkhasiat mengendalikan kadar gula darah. Obat antidiabetes oral mungkin berguna untuk penderita yang alergi terhadap insulin atau yang tidak menggunakan suntikan insulin. Sementara penggunaannya harus dipahami, agar ada kesesuaian dosis dengan indikasinya, tanpa menimbulkan hipoglikemia. Karena obat antidiabetes oral kebanyakan memberikan efek samping yang tidak diinginkan, maka para ahli mengembangkan sistem pengobatan tradisional untuk diabetes mellitus yang relatif aman.

Tanaman suweg telah banyak dikenal oleh masyarakat Indonesia. Tanaman ini tersebar di berbagai daerah, baik di pegunungan maupun di dataran rendah. Tanaman ini tumbuh di wilayah iklim tropis dan subtropis, termasuk di Asia Tenggara dan Cina. Di Indonesia pohon ini tumbuh di bawah tegakan pohon di pegunungan, tetapi ada juga yang ditanam orang untuk pangan alternatif (Heyne, 1987). Selain itu, dituliskan juga bahwa umbi suweg tersebut dapat digunakan untuk mengobati kencing manis atau diabetes mellitus (Hembing, 1996; Aliadi, 1996). Berdasarkan uraian tersebut di atas, maka dirumuskan permasalahan sebagai berikut: apakah umbi suweg dapat menurunkan kadar glukosa darah tikus putih? Tujuan penelitian ini adalah untuk mengetahui aktivitas pangan umbi suweg dalam menurunkan kadar glukosa darah tikus putih. Manfaat dari penelitian ini adalah dapat digunakannya umbi suweg sebagai alternatif dalam pengobatan diabetes mellitus melalui tikus dalam upaya untuk dapat diaplikasikan pada manusia.

\section{Metode}

Bahan yang digunakan dalam penelitian ini adalah umbi suweg berumur 8-10 bulan sejak penanaman sampai panen yang diperoleh dari hutan Jati Perhutani Sekepyar, Cagar Alam Pagerwunung Darupono, dan dari masyarakat desa Darupono Kaliwungu Kabupaten Kendal sebanyak 5 kg. Suweg (Amorphophallus campanulatus) dilakukan identifikasi tumbuhan terlebih dahulu untuk menentukan ketepatan bahan berupa spesies suweg (Amorphophallus campanulatus) supaya tidak keliru mana yang suweg mana yang porang atau mana yang walur. Determinasi dilakukan di laboratorium Biologi UIN Walisongo Semarang. Hewan coba berupa tikus putih jantan (Rattus novergicus) galur Sprague Dawley berasal dari Laboratorium Biologi Universitas Negeri Semarang. Pada prosedur pembuatan pakan umbi suweg, suweg dikupas terlebih dahulu memakai sarung tangan untuk menghindari rasa gatal. Tekstur umbi suweg yang padat, renyah dan keras memudahkan pengupasan. Setelah dikupas, umbi dipotong menjadi beberapa bagian, agar lebih mudah dalam pengolahannya. Kemudian umbi suweg dicuci bersih untuk membuang sisa kotoran dan lendir. Umbi suweg yang sudah dicuci bersih dipotongpotong menjadi bagian yang lebih kecil, yang nantinya potongan umbi suweg kecil tersebut akan dijemur di bawah sinar matahari untuk pengawetan alami atau dioven atau disangrai bila matahari tidak nampak karena mendung atau hujan. Hasil potongan umbi suweg yang berukuran sekitar $2 \mathrm{~cm}$ tersebut kemudian direbus sebagian dan sisanya yang mentah masing-masing ditimbang dengan berat yang sama 150 gr. Sisa suweg ditepungkan. Suweg dibagi untuk 2 perlakuan dan kontrol dengan masing-masing 5 kali ulangan. Masing masing tikus mendapat pakan dari suweg $10 \mathrm{gr}$. 
Eksperimen ini dilakukan di Laboratorium Hewan Universitas Negeri Semarang. Prosedur pengujian efek penurun Kadar Glukosa Darah (KGD) dimulai dengan bioassay secara invitro untuk mengetahui efek umbi suweg sebagai penurun berupa gula darah. Pengujian pangan berupa umbi suweg melibatkan sebanyak 15 ekor tikus putih sehat yang dimasukkan dalam kandang kolektif dengan suhu ruang $20-25^{\circ}$ Celcius. Tikus diberi makan standar dan minum. Semua tikus diadaptasikan selama satu minggu sebelum diberi perlakuan. Masing-masing tikus yang terdiri dari 5 ekor tikus normal diadaptasikan terhadap pakan selama 3 hari dan dipuasakan selama 8-12 jam kemudian diberi pakan sesuai dengan kelompok perlakuan masingmasing pakan $10 \mathrm{mg} / \mathrm{kg}$ BB. Berat tikus ditimbang setiap 3 hari. Bila berat sudah mencapai rata-rata 200-250 gram maka tikus siap diberi perlakuan. Sesuai kelompoknya masing-masing tikus diberi perlakuan dengan pakan umbi suweg rebus, umbi suweg mentah dan kontrol berupa pakan standar. Pengambilan sampel darah dilakukan pada akhir penelitian. Tikus dikeluarkan dari kandang dan di tempat terpisah dengan tikus lainnya kemudian ditunggu beberapa saat untuk mengurangi penderitaan pada tikus akibat aktivitas antara lain, pemindahan, penanganan, atau gangguan. Kadar glukosa darah dilihat dengan glukometer pada menit ke 0, 60 dan 120 setelah pemberian pakan secara oral. Kemudian hasil dicatat dalam tabel pengamatan untuk dianalisis apakah benar ada penurunan dari kadar glukosa darah.

\section{Hasil dan Pembahasan}

Sebelum penelitian dilakukan, suweg dipersiapkan terlebih dahulu sebanyak $5 \mathrm{~kg}$, setelah dikupas dan dijemur tinggal 1,71 kg. Hewan uji berupa 15 ekor tikus putih. Setelah dilakukan percobaan pada tikus putih sebanyak 15 ekor (5 ekor diberi pakan umbi suweg rebus, 5 ekor diberi pakan suweg mentah dan 5 ekor kontrol dengan pakan standar). Masing-masing pakan $10 \mathrm{mg} / \mathrm{kg}$ BB. Setelah diberikan pakan dan sisa pakan juga dihitung maka didapatkan hasil sebagai berikut.

Tabel 1. Data hasil pengukuran KGD (Kadar Gula darah) treatment umbi suweg

\begin{tabular}{|c|c|c|c|c|c|c|c|}
\hline \multirow[t]{2}{*}{ Kelompok } & \multirow[t]{2}{*}{ Tikus ke- } & \multirow{2}{*}{$\begin{array}{l}\text { BB } \\
(\mathrm{g})\end{array}$} & \multicolumn{2}{|c|}{ Pakan (g) } & \multicolumn{3}{|c|}{$\mathrm{KGD}(\mathrm{mg} / \mathrm{dl})$} \\
\hline & & & Awal & Sisa & 0 jam & 1 jam & 2 jam \\
\hline \multirow[t]{5}{*}{ Kontrol } & 1 & 180 & 10 & 1 & 94 & 117 & 121 \\
\hline & 2 & 175 & 10 & 3 & 90 & 117 & 125 \\
\hline & 3 & 182 & 10 & 2 & 85 & 120 & 126 \\
\hline & 4 & 183 & 10 & 1 & 100 & 120 & 120 \\
\hline & 5 & 188 & 10 & 0 & 111 & 100 & 126 \\
\hline Rerata & & 181,6 & & 1,4 & 96 & 114,8 & 123,6 \\
\hline \multirow{5}{*}{$\begin{array}{l}\text { Suweg } \\
\text { rebus }\end{array}$} & 1 & 190 & 10 & 3 & 92 & 99 & 118 \\
\hline & 2 & 188 & 10 & 4 & 97 & 112 & 119 \\
\hline & 3 & 180 & 10 & 3 & 85 & 117 & 118 \\
\hline & 4 & 173 & 10 & 4 & 110 & 125 & 120 \\
\hline & 5 & 176 & 10 & 2 & 112 & 124 & 120 \\
\hline Rerata & & 181,4 & & 3,2 & 99,2 & 115,4 & 119 \\
\hline \multirow{4}{*}{$\begin{array}{l}\text { Suweg } \\
\text { mentah }\end{array}$} & 1 & 170 & 10 & 7 & 85 & 87 & 98 \\
\hline & 2 & 186 & 10 & 6 & 89 & 96 & 85 \\
\hline & 3 & 189 & 10 & 8 & 87 & 98 & 88 \\
\hline & 4 & 190 & 10 & 5 & 84 & 87 & 80 \\
\hline
\end{tabular}




\begin{tabular}{|l|c|c|c|c|c|c|c|} 
& 5 & 183 & 10 & 7 & 110 & 120 & 118 \\
\hline Rerata & & 183,6 & & 6,6 & 91 & 97,6 & 93,8 \\
\hline
\end{tabular}

Pemberian pakan berupa suweg rebus dan suweg mentah pada tikus ditujukan untuk mengetahui respon tubuh dalam mengatasi kenaikan kadar gula sewaktu setelah pemberian pakan tersebut. Kelompok tikus yang diberi pakan normal (kontrol) menunjukkan rerata konsumsi pakan selama perlakuan adalah $0.05 \mathrm{~g} / \mathrm{g}$ BB. Kelompok tikus dengan pemberian pakan berupa suweg rebus menunjukkan rerata konsumsi pakan yang sedikit lebih rendah, yaitu sebesar $0.04 \mathrm{~g} / \mathrm{g}$ BB berat badan. Konsumsi pakan terendah ditunjukkan oleh kelompok tikus yang diberi pakan berupa suweg mentah. Gambaran rerata konsumsi pakan tersebut dapat dilihat dari Tabel 2 dan Gambar 1 berikut.

Tabel 2. Rerata Konsumsi Pakan Per Gram Berat Badan

\begin{tabular}{|l|l|c|c|c|c|}
\hline No. & \multicolumn{1}{|c|}{ Perlakuan } & $\begin{array}{c}\text { Rerata } \\
\text { Berat } \\
\text { Badan }\end{array}$ & $\begin{array}{c}\text { Rerata } \\
\text { Ketersediaan } \\
\text { Pakan (g) }\end{array}$ & $\begin{array}{c}\text { Rerata } \\
\text { Terkonsumsi }\end{array}$ & $\begin{array}{c}\text { Rerata Konsumsi } \\
\text { Pakan /g BB }\end{array}$ \\
\hline 1 & Kontrol & 181.6 & 10 & 8.6 & 0.05 \\
\hline 2 & Suweg rebus & 181.7 & 10 & 6.8 & 0.04 \\
\hline 3 & Suweg mentah & 183.6 & 10 & 3.4 & 0.02 \\
\hline
\end{tabular}

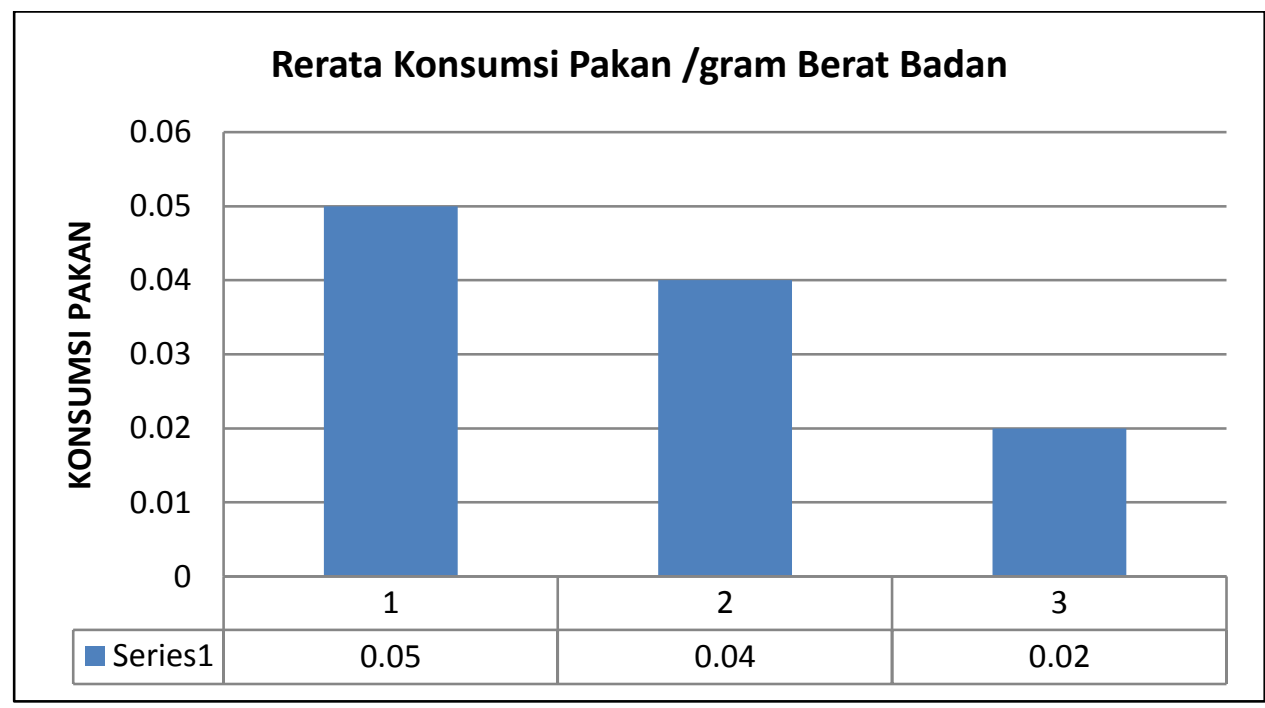

Gambar 1. Rerata Konsumsi Pakan/gr Berat Badan

Gambaran tersebut menunjukkan bahwa tikus kurang menyukai pakan dari jenis suweg mentah. Suweg mentah (tidak direbus) memiliki tekstur yang lebih keras dan meninggalkan rasa getir saat dikonsumsi. Perebusan dapat memperbaiki tekstur, daya cerna, dan rasa dari suweg.
Proses perebusan di sisi lain juga memiliki kecenderungan untuk mengurangi aktivitas dan struktur dari beberapa bahan aktif yang berupa metabolit sekunder. Bahan aktif tersebut dapat berkurang kadarnya akibat proses pemanasan. Pemanasan berlebih umumnya dapat mengurai dan merusak struktur kompleks, terutama bahan aktif yang tergolong protein. Bahan aktif yang larut 
dalam air pun cenderung akan larut saat proses perebusan.

Bahan aktif dari suweg berdasarkan penelitian yang pernah dilakukan menunjukkan kemampuan dalam menurunkan kadar gula darah tikus. Hal ini menjelaskan bahwa pada perlakuan pakan suweg mentah kadar gula darah pada kelompok tikus menunjukkan kecenderungan menurun. Berbeda dengan gula darah perlakuan pemberian pakan berupa suweg rebus maupun kontrol yang menunjukkan kecenderungan meningkat. Gambaran perubahan kadar gula antar perlakuan tersebut dapat dilihat pada Tabel 3 dan Gambar 2.

Tabel 3. Rerata Perubahan Kadar Gula Darah Tikus Antar Perlakuan

\begin{tabular}{|l|l|c|c|c|}
\hline \multirow{2}{*}{ No. } & \multirow{2}{*}{ Perlakuan } & \multicolumn{3}{|c|}{ Perubahan Kadar Gula Darah } \\
\cline { 3 - 5 } & & 0 jam & 1 jam & 2 jam \\
\hline 1 & Kontrol & 96 & 114.8 & 123.6 \\
\hline 2 & Suweg rebus & 99.2 & 115.4 & 119 \\
\hline 3 & Suweg mentah & 91 & 97.6 & 93.8 \\
\hline
\end{tabular}

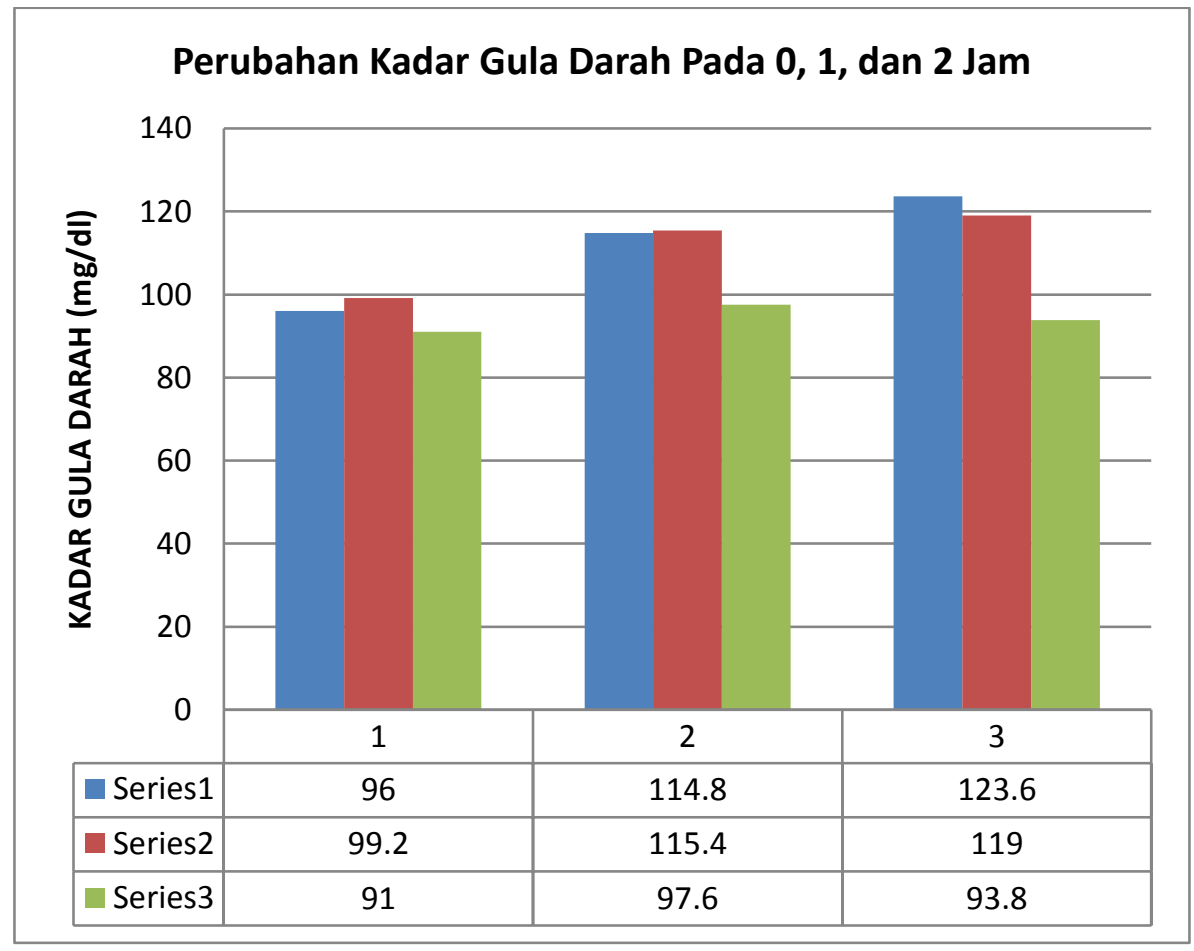

Gambar 2. Rerata Perubahan Kadar Gula Darah Tikus antar Perlakuan

Gambaran yang ditunjukkan oleh Gambar 2 menjelaskan bahwa secara umum gula darah meningkat pada 1 jam pertama setelah perlakuan pemberian pakan. Penurunan kadar gula dari kenaikan setelah 1 jam pertama tersebut hanya terlihat pada pemberian pakan berupa suweg mentah setelah 2 jam perlakuan.

Gambaran selisih perubahan kadar gula darah antar waktu perlakuan dari jam ke-0 ke 


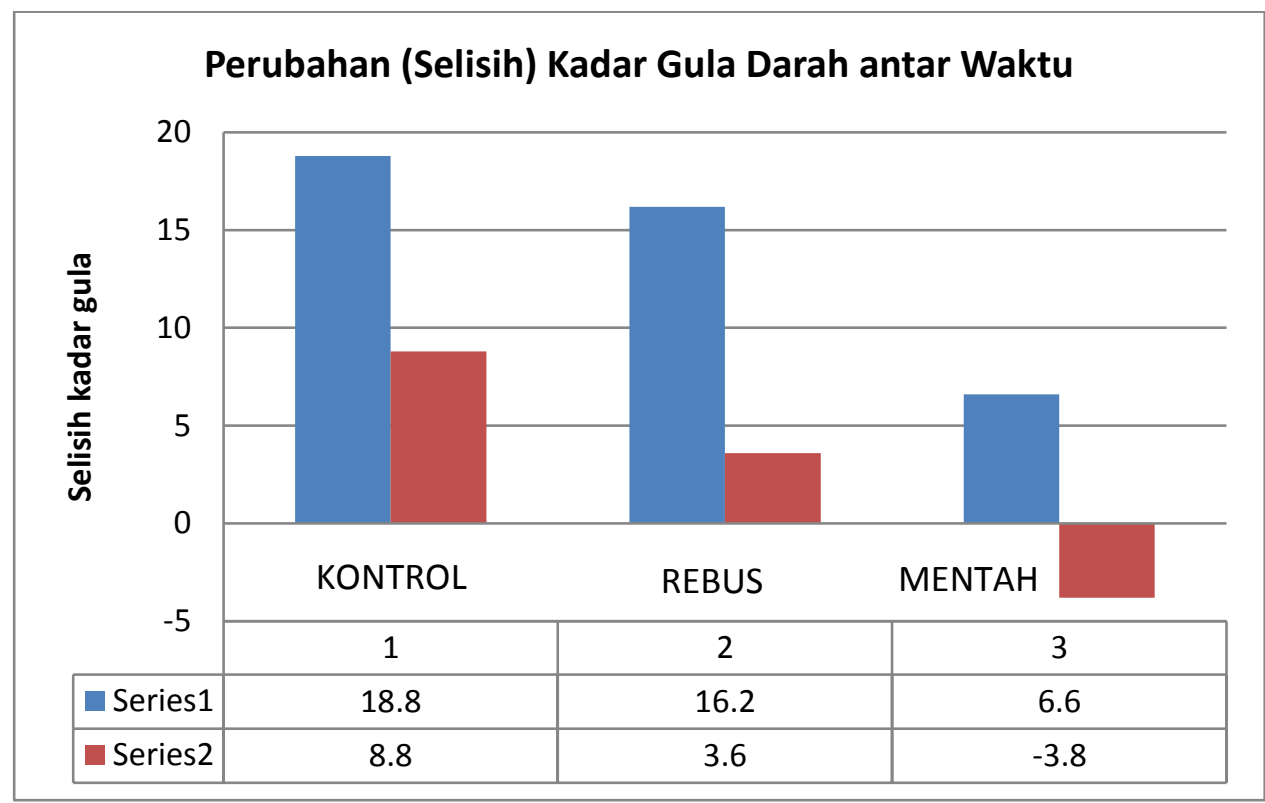

Gambar 3. Perubahan selisih kadar gula darah antar waktu

Selisih perubahan kadar gula darah antar waktu perlakuan dari jam ke-0 ke pengukuran jam ke-1 menunjukkan bahwa peningkatan kadar gula terrendah adalah pada pemberian pakan berupa suweg mentah, yaitu meningkat hanya sebesar 6,6 $\mathrm{mg} / \mathrm{dl}$, jika dibandingkan perlakuan lainnya (kontrol = $18.8 \mathrm{mg} / \mathrm{dl}$; suweg rebus $=16.2 \mathrm{mg} / \mathrm{dl}$ ). Pengukuran kadar gula darah pada jam ke-2 menunjukkan perubahan yang bervariasi. Peningkatan kadar gula pada pemberian pakan berupa suweg rebus pada pengukuran jam ke-2 sebesar 3,6 mg/dl. Nilai tersebut lebih rendah dari peningkatan kadar gula darah pada perlakuan kontrol, yaitu sebesar $8.8 \mathrm{mg} / \mathrm{dl}$.

Berbeda dengan kontrol dan perlakuan pemberian pakan suweg rebus, pada pemberian pakan berupa suweg mentah menunjukkan kecenderungan menurun pada pengukuran jam ke2. Penurunan kadar gula pada kelompok tikus dengan pemberian pakan suweg mentah tersebut sebesar 3,8 mg/dl. Nilai tersebut lebih rendah daripada pengukuran jam ke-1 dari kelompok perlakuan yang sama.
Peningkatan kadar gula baik pada perlakuan kontrol maupun perlakuan suweg rebus dari jam ke-1 ke jam ke-2 lebih rendah jika dibandingkan dengan peningkatan dari jam ke-0 ke jam ke-2. Kecenderungan ini menunjukkan bahwa secara alami hormon insulin di dalam tubuh tikus sudah mulai bekerja dalam menyeimbangkan kadar gula darah tubuh. Selisih nilai kadar gula darah antara perlakuan kontrol dengan perlakuan suweg mentah menunjukkan kecenderungan perbedaan kecepatan metabolisme tubuh dalam menyerap gula darah. Di dalam tubuh terdapat darah. Dalam darah tersebut memiliki zat glukosa yang digunakan untuk dibakar agar mendapatkan energi atau kalori. Glukosa yang sebagian berasal dari dalam darah berasal dari hasil penyerapan usus. Selain itu juga glukosa berasal dari pemecahan simpanan energi dalam jaringan. Glukosa yang ada pada usus bisa juga berasal dari makanan yang kita makan (Wulandari, 2010).

Kadar glukosa dalam darah bervariasi dengan penyerapan. Glukosa akan menjadi lebih tinggi setelah makan dan akan turun bila tidak ada makanan yang masuk selama beberapa jam. Glukosa disimpan sebagai glikogen di dalam sel hati 
oleh insulin. Glikogen akan dibuat menjadi glukosa oleh glukogen (Setiawan dkk, 2007). Pada suatu saat kadar glukosa dalam tubuh dapat mengalami peningkatan. Kelebihan kadar glukosa dalam darah disebut hiperglikemia. Hiperglikemia adalah keadaan dimana kadar gula darah melonjak atau berlebihan, yang akhirnya akan menjadi penyakit yang disebut Diabetes Melitus (DM) yaitu suatu kelainan yang terjadi akibat tubuh kekurangan hormon insulin, akibatnya glukosa tetap beredar di dalam aliran darah dan sukar menembus dinding sel. Keadaan ini biasanya disebabkan oleh stress, infeksi, dan konsumsi obat-obatan tertentu. Hiperglikemia ditandai dengan poliuria, polidipsi, dan polifagia, serta kelelahan yang parah dan pandangan yang kabur. Selain itu ada kekurangan gula darah yang dapat terjadi pada manusia atau biasa disebut hipoglikemia. Hipoglikemia atau penurunan kadar gula darah merupakan keadaan dimana kadar glukosa darah berada di bawah normal, yang dapat terjadi karena ketidakseimbangan antara makanan yang dimakan, aktivitas fisik dan obat-obatan yang digunakan. Sindrom hipoglikemia ditandai dengan gejala klinis antara lain penderita merasa pusing, lemas, gemetar, pandangan menjadi kabur dan gelap,berkeringat dingin, detak jantung meningkat dan terkadang sampai hilang kesadaran/syok hipoglikemia (Simon, 2011).

Penurunan nilai kadar gula darah pada pemberian suweg mentah pada pengukuran dari jam ke-1 ke jam ke-2 menunjukkan bahwa selain tubuh melakukan usaha homeostasis pada kadar gula darah, bahan aktif dari suweg mentah diduga turut menyumbang dalam mempercepat penurunan kadar gula darah pada tikus uji. Cadangan makanan yang tersimpan dalam umbi umumnya adalah dalam bentuk polisakarida, dengan sedikit campuran oligosakarida, dan monosakarida. Bentuk polisakarida yang paling umum adalah pati, yang merupakan polimer dari glukosa dalam bentuk amilosa (tidak bercabang) dan atau amilopektin (bercabang) (Price, 2005). Umbi suweg memiliki kandungan senyawa bioaktif yaitu serat pangan dan polisakarida larut air yang mampu menurunkan kadar gula darah.

Serat makanan adalah komponen bahan makanan nabati penting yang tahan terhadap proses hidrolisis oleh enzim-enzim pada sistem pencernaan manusia. Komponen yang terbanyak dari serat pangan ditemukan pada dinding sel tanaman. Komponen ini termasuk senyawa struktural seperti selulosa, hemiselulosa, pektin, dan lignin. Serat pangan dapat diklasifikasikan berdasarkan struktur molekul dan kelarutannya. Kebanyakan jenis karbohidrat yang sampai ke kolon tanpa terhidrolisis meliputi polisakarida yang bukan pati (non-starch polysaccharides = NSP), pati yang resisten (resistant starch = RS), dan karbohidrat rantai pendek (short chaincarbohydrates $=\mathrm{SC}$ ). Serat pangan yang larut sangat mudah difermentasikan dan mempengaruhi metabolisme karbohidrat serta lipida, sedangkan serat pangan yang tidak larut akan memperbesar volume feses dan akan mengurangi waktu transitnya (bersifat laksatif lemah). Monomer dari serat pangan (NSP) adalah gula netral dan gula asam, sedangkan lignin terdiri dari monomer aromatik.

Gula-gula yang membentuk serat pangan yakni glukosa, galaktosa, xilosa, mannosa, arabinosa, rhamnosa, dan gula asam, yakni mannuronat, galakturonat, glukoronat, serta 4-0metil-glukoronat. Rangkaian NSP yang dibentuk oleh monosakarida ini dihubungkan melalui ikatan b (1-4) glikosida contohnya pektin, sellulosa, dan gum.Oleh karena itu, serat pangan tersebut (NSP) tidak dapat dihidrolisis oleh enzim percerna manusia. Misalnya, pektin mengandung asam galakturonat, baik yang termetilasi maupun yang tidak. Perbandingan dari metilasi dan sebagai asam (derajat metilasi) dalam polimer pektin, sangat berpengaruh terhadap sifat fungsional dari pektin. Pektin dengan derajat metilasi yang tinggi (high- 
methoxy pectin = HMP) yang terdapat secara alamiah pada buah dan sayuran, mungkin tidak larut (Torsdottir et al., 2001). PLA merupakan serat pangan larut air yang didefinisikan sebagai komponen dalam tanaman yang tidak terdegradasi secara enzimatis menjadi sub unit-sub unit yang dapat diserap di lambung dan usus halus. PLA biasanya juga disebut hidrokoloid, dewasa ini banyak sekali dimanfaatkan dalam industri makanan, guna mencapai kualitas yang diharapkan dalam hal viscositas, stabilitas, tekstur, dan penampilan. Kandungan makro molekul yang terdiri dari polisakarida kompleks dan struktur molekulnya berantai cabang molekul polisakarida yang membentuk PLA adalah hasil kondensasi dari monosakarida (pentosa dan heksosa) dan asam organik yang terbentuk dari gula-gula reduksi. Jika PLA dihidrolisis akan menghasikan bermacam macam monosakarida antara lain rhamonosa, fruktosa (metil pentosa), arabinosa, D-glukosa, Dmannosa, D-galaktosa, asam D-galakturonat atau asam D-glikoronat (Tensiska, 2008).

Pada komponennya serat pangan dapat diklasifikasikan berdasarkan struktur molekul dan kelarutannya. Serat makanan berdasarkan kelarutan terdiri atas serat larut dan serat tidak larut. Contoh serat pangan yang tidak larut adalah selulosa, hemiselulosa, dan lignin. Contoh serat larut adalah pektin, gum, musilase, glukan dan alga (Almatseir, 2001). Lalu serat larut air adalah jenis serat yang dapat berfungsi sebagai zat pembersih saluran cerna yang dapat membantu melancarkan buang air besar. Serat tidak larut air akan terbawa melewati saluran cerna hingga ke usus besar. Kanker kolon yang selama ini menjadi masalah kesehatan di negara barat ternyata termasuk kasus kanker yang terbanyak juga di Indonesia. Risiko kanker ini dapat diturunkan dengan meningkatkan asupan serat, terutama serat tak larut ini (Nainggolan dan Adimunca, 2005).

Serat makanan berasal dari bagian tumbuhan yang tidak dapat dicerna oleh enzim dalam saluran usus. Namun demikian bagian larut air dari serat tersebut dapat dimetabolisme oleh bakteri di dalam usus bagian bawah. Serat makanan dapat ditemukan pada buah-buahan, sayur-sayuran, serealia, umbi, dan kacang-kacangan. Jumlah serat pangan yang harus dikonsumsi adalah 20 - 35 g/hari (Nielsen, 1998).

Pada manusia etika mengkonsumsi makanan yang memiliki banyak kandungan serat larut air pada makanan yang dia konsumsi, dalam lambung, serat larut air tersebut akan membentuk gel karena adanya reaksi serat dengan air. Gel akan membuat lambung penuh dan mengirim sinyal ke otak bahwa lambung sudah terisi penuh atau kenyang. Nantinya pada penderita diabetes hal ini menjadi dasar untuk penyembuhan penyakitnya karena ringannya pekerjaan insulin karena gula yang dipecah sedikit menyebabkan adanya waktu perbaikan fungsi insulin kembali. Biasanya serat larut air di dapat dari buah dan umbi umbian (Nainggolan dan Adimunca, 2005).

Pada Polisakarida larut air misalnya pektin, $\beta$-glukan, dan gum dan beberapa hemiselulosa mempunyai kemampuan menahan air dan dapat membentuk cairan kental dalam saluran pencernaan. Dengan kemampuan ini serat larut dapat menunda pengosongan makanan dari lambung, menghambat pencampuran isi saluran cerna dengan enzim pencernaan yang menyebabkan terjadinya pengurangan penyerapan zat makanan di bagian proksimal. Mekanisme inilah yang menyebabkan terjadinya penurunan penyerapan (absorbsi) asam amino dan asam lemak oleh serat larut air. Cairan kental ini mengurangi keberadaan asam amino dalam tubuh melalui penghambatan peptida usus (Nainggolan dan Adimunca. 2005). Kandungan PLA dan serat pangan dari umbi-umbian tersebut diduga yang menyebabkan penurunan kadar glukosa darah. Serat pangan mempunyai kemampuan menurunkan glukosa darah melalui mekanisme penghambatan penyerapan glukosa ke dalam 
darah. Dalam suatu penelitian menyebutkan pada penelitiannya hasil ekstraksi PLA pada Suweg mempunyai efek penurunan glukosa darah hingga $84.17 \mathrm{mg} / \mathrm{dl}$. Nilai tersebut termasuk dalam keadaan glukosa darah puasa normal $\quad<110$ $\mathrm{mg} / \mathrm{dL}$ ). Hal ini membuktikan bahwa PLA mampu menurunkan kadar glukosa darah (Harsono, 2012).

Aplikasi umbi suweg berdasarkan data dari penelitian tersebut masih perlu dilanjutkan terutama dalam meramu sediaan. Pemberian umbi suweg sebagai pakan tunggal memiliki kelemahan pada ketercernaannya. Tekstur yang keras serta kurangnya rasa dari umbi suweg mentah kurang dapat diterima. Perlakuan perebusan pada suweg berdasarkan data tersebut juga tidak dapat mempercepat penurunan kadar gula darah. Perlakuan perebusan pada umbi suweg selain mengurangi aktivitas dari bahan aktifnya juga menambah ketercernaan dari karbohidrat yang di kandungnya. Penyederhanaan karbohidrat menjadi gula yang lebih sederhana secara umum memiliki kecenderungan dalam meningkatkan kadar gula darah. Ekstraksi bahan aktif dari suweg sebaiknya dilakukan apabila ditujukan untuk menurunkan kadar gula darah secara lebih efektif, apalagi jika ditujukan sebagai obat pada penderita diabetes mellitus. Uji lanjut pun masih perlu dilakukan untuk mengkaji kemampuan dari ekstrak umbi suweg hingga nantinya dapat diaplikasikan pada penderita diabetes mellitus.Umbi suweg juga mengandung zat kimia seperti flavonoid dan saponin sedangkan daun dan batang suweg mengandung saponin dan polifenol. Konsumsi suweg rebus lebih sesuai untuk diaplikasikan pada diet rendah gula dibandingkan untuk penurunan kadar gula secara langsung. Kadar karbohidrat yang rendah dari umbi suweg dibandingkan umbi lainnya menjadikan umbi suweg dapat diaplikasikan untuk diet rendah gulabahwa kadar karbohidrat suweg paling rendah yakni 15,7 (Kam Nio dalam Budiono, 1995). Umbi suweg merupakan sebagian umbi-umbian lokal inferior yang memiliki manfaat sebagai pangan fungsional yang berguna untuk menurunkan kadar glukosa darah. Kemampuan umbi-umbian tersebut untuk menurunkan kadar glukosa darah didapat dari senyawa bioaktif yang dimiliki yaitu Polisakarida Larut Air (PLA) dan serat pangan.

\section{Kesimpulan}

Suweg mentah pada dosis $10 \mathrm{mg} / 180 \mathrm{~g} \mathrm{BB}$ lebih cepat berkhasiat menurunkan kadar glukosa darah tikus putih 3,8 mg/dl dibanding suweg rebus dosis $10 \mathrm{mg} / \mathrm{Kg}$ BB yakni 3,6 mg/dl. Bagian bioaktif yang berperan menurunkan Kadar Glukosa Darah adalah polisakarida (Larut Air PLA) dan serat pangan. Namun rasa suweg mentah menyebabkan muntah dan gatal di lidah dan kerongkongan sehingga tidak disarankan mengonsumsi umbi suweg mentah. Rasa gatal diduga mengandung oksalat, melalui perebusan oksalat akan larut dan hilang. Ekstraksi bahan aktif dari suweg sebaiknya dilakukan apabila ditujukan untuk menurunkan kadar gula darah secara lebih efektif. Uji lanjutperlu dilakukan dengan beberapa dosis yang berbeda untuk mengkaji kemampuan ekstrak umbi suweg lebih lanjut hingga nantinya dapat diaplikasikan pada penderita diabetes mellitus.

\section{Ucapan Terima Kasih}

Pada kesempatan ini, kami ingin menyampaikan terima kasih yang sebesar-besarnya kepada Ketua Lembaga Penelitian dan Pengabdian Universitas Islam Negeri Walisongo Semarang atas kebijaksanaannya sehingga penelitian ini dapat didanai.

\section{DAFTAR PUSTAKA}

Adam, J.M.F. 2000. Klasifikasi dan Kriteria Diagnosis Diabetes Melitus yang Baru. Endokrin dan Metabolik Bagian Ilmu Penyakit Dalam. Fakultas Kedokteran, Universitas Hasanuddin. Ujung Pandang.

Amorphophallus paeoniifolius (Dennst.) Nicolson dalam ITIS Report.

Amorphophallus paeoniifolius (Dennst.) Nicolson dalam Plants Database dari USDA 
Bargumono dan Wongsowijaya, S. 2013. Sembilan Umbi Utama Sebagai Pangan Alternatif Nasional. Leutika Prio. Yogyakarta.

Baynes, J.W. 2003. Role of oxidative stress in diabetic complications, a new perspective on an old paradigm. Diabetes, 48: 1-9.

Brand-Miller, J. Wolever, T.M.S., Colagiuri, S., dan Foster-Powell, K. 2000. Glycemic Index, Carbohydrate and Fat. www.glycemicindex.ca/glycemicindexfoods. pdf. Tanggal akses: 29/01/2011.

Budoyo, S. 2010. Kandungan Karbohidrat dan Pola Pita Isozim Pada Varietas Lokal Ubi Kelapa (Dioscorea alata) di Kabupaten Karanganyar. Tesis Program Studi Biosains, Program Pascasarjana, Universitas Sebelas Maret. Surakarta.

De, S., Y.N. Dey, dan A.K. Gosh. 2010. Phytochemical Investigation and Chromatographic Evaluation of the Different Extracts of Tuber of Amorphallus Paeoniifolius (Araceae). International Journal on Pharmaceutical and Biomedical Research (IJPBR), Vol. 1 (5): 150157.

Dennstedt, A.W. 1818. Schlüssel zum Hortus Indicus Malabaricus, oder dreifaches Register zu diesem Werke p. 13, 21, 38. Weimar: im Verlage des Landes - Ind.- Compt.

Evans, Joseph, dkk. 2002. Oxidative Stress and Stress-Activated Signaling Pathways: A Unifying Hypothesis of Type 2 Diabetes. Endo crine Reviews, 23 (5): 599-622.

Ezeocha, V.C. dan Ojimelukwe, P.C. 2012. The impact of cooking on the proximate composition and anti-nutritional factors of water yam (Dioscorea alata). Journal of Stored Products and Postharvest Research, Vol. 3 (13): 172176.

Harijono, Teti Estiasih, Wenny Bekti, dan Komang Suwito, 2012. Efek Hipoglikemik Polisakarida Larut Air Gembili (Dioscorea esculenta) yang Diekstrak dengan Berbagai Metode. J. Teknologi dan Industri Pangan, Vol. XXIII No. 1.

Harsono, Maino Dwi. 2012. Efek Hipoglikemik Biskuit Mengandung Polisakarida Larut Air Umbi Gadung dan Umbi Gembili dan Alginat pada Tikus Diabetes. Jurusan Teknologi Hasil Pertanian. Universitas Brawijaya. Malang.
Heyne, K. 1987. Tumbuhan Berguna Indonesia, Jilid III. Badan Penelitian dan Pengembangan Kehutanan, Departemen Kesehatan Republik Indonesia. Jakarta.

Jatmiko, Ginanjar Putra. 2013. Karakteristik Fisiko Kimia, Bioaktif, dan Organoleptik Mie dari Umbi Kimpul (Xanthosoma sagittifolium). Skripsi. Universitas Brawijaya. Malang.

Kurniawan, Agung. 2013. Karakteristik Fisiko Kimia, Bioaktif, dan Organoleptik Mie Dari Umbi Garut. Skripsi. Universitas Brawijaya. Malang.

Kurnia, K. 2002. Cara Aman Mengkonsumsi Gadung. http://www.pikiranrakyat.com/cekt/1202/ 22/2002. Tanggal akses: 23/12/2009.

Lako, J., V.C. Trenerry, M. Wahlqvist, N. Wattanapenpaiboon, S. Sotheeswaran, dan R. Premier. 2007. Phytochemical flavonols, carotenoids, and the antioxidant properties of a wide selection of Fijian fruit, vegetables and other readily available foods. doi: 10.1016/j.foodchem.2006.01.031.

Li, C. dan Manddep, U. 2010. Canadian Diabetes Association National Nutrition Committee Clinical Update on Diatery Fibre in Diabetes: Food Sources to Physiological Effect. Canadian Journal of Diabetes 34 (4): 355361.

Luthana, Y.K. 2009. Asam Lemak Rantai Pendek. http://www.yongkikastanyaluthana.wordpr ess.com/2009/03/12/asam-lemak-rantaipendek. Tanggal akses: 23/12/2010.

Mao, X., Y. Wu, K. Wu, M. Liu, J. Zhang, F. Zou, dan J. Ou-Yang. 2007. Astragalus polysaccharide reduces hepatic endoplasmic reticulum stress and restores glucose homeostasis in a diabetic KKAy mouse model. Acta Pharmacol Sin 28 (12): 1947-1956.

Mar'atirrosyidah, R. dan Estiasih, T. 2015. Aktivitas Antioksidan Senyawa Bioaktif Umbi-umbian Lokal Inferior: Kajian Pustaka. Jurnal Pangan dan Agroindustri, Vol. 3 (2): 594-601.

Maulida, Deni dan Estiasih, Teti. 2014. Efek Hipoglikemik PLA Umbi Gadung. Jurnal Pangan dan Agroindustri, Vol. 2, No. 3, Hal. 136-140.

Moharib, S.A. dan El-Batran, S.A. 2008. Hypoglycemic Effect of Dietary Fibre in 
Diabetic Rats. Research Journal of Agriculture and Biological Science, 4 (5): 455-460.

Nainggolan, O dan Adimunca, C. 2005. Diet Sehat Dengan Serat. Cermin Dunia Kedokteran No. 147.

Nielsen, S.S. 1998. Food Analysis Second Edition. Aspen Publishers, Inc. Indiana.

Octa. 2005. Diabetes Mellitus Masalah Kesehatan Masyarakat Yang Serius. http://www.depkes.go.id. Tanggal akses: 11/04/2014.

Permatasari, A. 2008. Uji Efek Penurunan Kadar Glukosa Darah Ekstrak Etanol 70\% Buah Jambu Biji pada Kelinci Jantan Lokal. Skripsi. Fakultas Farmasi Universitas Muhammadiyah. Surakarta.

Prabowo, Aditya Yoga. 2013. Karakteristik Fisiko Kimia, Bioaktif, dan Organoleptik Mie Dari Umbi Gembili. Skripsi. Universitas Brawijaya. Malang.

Price, Sylvia A. 2005. Patofisiologi Konsep Klinis Proses-Proses Penyakit, Volume 2. EGC. Jakarta

Rahman, Aulia. 2013. Karakteristik Fisiko Kimia, Bioaktif, Dan Organoleptik Mie Dari Ubi Kelapa. Skripsi. Universitas Brawijaya. Malang.

Rahmawati, A. 2010. Efek Hipoglikemik Ekstrak Kasar Polisakarida Larut Air Non-Pati Umbi Gadung (Dioscorea hispida Dennst.) yang Diperoleh dari Berbagai Metode Ekstraksi pada Tikus Hiperglikemia. Tesis. Universitas Brawijaya. Malang.

Rheede. 1692. Hortus Indicus Malabaricus : continens regni Malabarici apud Indos cereberrimi onmis generis plantas rariores ... XI: 37, tab. 19. Amstelaedami :sumptibus Johannis van Someren, et Joannis van Dyck.

Ridal, S. 2003. Karakterisasi Sifat Fisiko Kimia Tepung dan Pati Talas (Colocasia esculenta) dan Kimpul (Xanthoshoma sp) dan Uji Penerimaan Alfa Amylase terhadap Patinya. Skripsi. Fakultas Teknologi Pertanian, Institut Pertanian Bogor. Bogor.

Saputro, Prasetyo Sonny dan Estiasih, Teti. 2015. Pengaruh Polisakarida Larut Air (PLA) dan Serat Pangan Umbi-Umbian Terhadap Glukosa Darah: Kajian Pustaka. Jurnal
Pangan dan Agroindustri, Vol. 3 No. 2, Hal. 756-762.

Setiawan, dkk. 2007. Buku Ajar Fisiologi Kedokteran Edisi 9. Penerbit Buku Kedokteran EGC. Jakarta.

Silalahi, J. dan Hutagalung N. 2008. KomponenKomponen Bioaktif dalam Makanan dan Pengaruhnya Terhadap Kesehatan. Jurusan Farmasi Fakultas MIPA Universitas Sumatera Utara. Medan.

Simon, Harvey. 2011. Type 1 Diabetes Causes - Islets of Langerhans. http://www.healthcentral.com/diabetes/ty pe-I-diabetes-000009_2-145.html. Tanggal akses: 3/02/2014.

Skyler, J.S. 2004. Determination of carboxylic acids and inorganic anions in wines by ionexchange chromatography. J. Med. Chem. 47: 4113-4117.

Steffen, C. 2010. Diabetes and Insulin. Pharmacy Technician Program. Milwaukee Area. USA.

Sukamdani, H. 2012. Peningkatan Kualitas Flakes Ganyong (Canna edulis Ker.) dan Bekatul Menggunakan Variasi Sayuran. Skripsi. Program Studi Biologi, Fakultas Teknobiologi, Universitas Atma Jaya. Yogyakarta.

Sumunar, Siwi Ratna. 2013. Karakteristik Fisiko Kimia, Bioaktif, Dan Organoleptik Mie Dari Umbi Gadung. Skripsi. Universitas Brawijaya. Malang

Sunarsih, E.S., Djatmika, dan Utomo, R.S. 2007. Pengaruh Pemberian Infusa Umbi Gadung (Dioscorea hispida Dennst.) terhadap Penurunan Kadar Glukosa Darah Tikus Putih Jantan Diabetes yang Diinduksi Aloksan. Majalah Farmasi Indonesia 18 (1): 29-33.

Suprapti, L. 2003. Tepung Ubi Jalar: Pembuatan dan Pemanfaatannya. Kanisius. Yogyakarta.

Tandra, H. 2008. Segala Sesuatu yang Harus Anda Ketahui tentang Diabetes. PT. Gramedia Pustaka Utama. Jakarta.

Tensiska. 2008. Serat Makanan. Jurusan Teknologi Industri Pangan, Fakultas Industri Pertanian, Universitas Padjajaran. Bandung.

Tjokroprawiro A. 1986. Diabetes Melitus Aspek Klinik dan Epidemiologi. Airlangga University Press. Surabaya. 
Tjokroprawiro A. 1980. Prevalensi Diabetes Melitus Dewasa di Kodya Surabaya. Lembaga Penelitian Universitas Airlangga. Surabaya.

Torsdottir, I., M. Alpsten, G. Holm, F.A. Sandberg, dan J. Ta-Lli. 1991. A Small Dose of Soluble Alginate-Fiber Affects Postprandial Glycemia and Gastric Emptying In Humans With Diabetes. J. Nutr. 121: 795-799.

Torsdottir, I. et al. 2001. A Small Dose of Soluble Alginate-Fiber Affects Postprandial Glycemia and Gastric Emptying in Humans with Diabetes. Departement of Clinical Nutritions. Sweden

Wulandari, Shinta. 2010. Pengaruh Pemberian Cuka Apel Dan Cuka Salak Terhadap Kadar Glukosa Darah Pada Tikus Wistar Jantan Yang Diberi Diet Tinggi Gula. Skripsi. Jurusan Teknologi Hasil Pertanian, Fakultas Teknologi Pertanian, Universitas Brawijaya. Malang. 